\title{
Der var engang en høg Jens Nauntofte
}

\section{Man bliver klogere af Pundiks pletskud, hvor han ser om hjørner og opdager de fejltagelser Mellem- østens politikere er på vej ind i}

Anders Jerichow(red): Pundik. Udvalgte artikler fra 1946 til i dag. Politikens forlag 2007.

Herbert Pundik nægter at lade alderen trænge ind i sit liv - som journalist. Det fremgår tydeligt af de artikler fra en 61-årig løbebane, som er blevet samlet i anledning af hans 80 års fødselsdag. Anders Jerichow har været langt omkring i Pundiks arkiv for at finde så velskrevne artikler som muligt. Det har øjensynligt ikke været svært. For Herbert Pundik skriver som en engel, når han er bedst.

Som en maler laver han en hurtig skitse hen over blokken og stregen er skarp og knap: "Mogadishu er en by - det må man lade den. 3 biografer, 148 moskeer, en italiensk triumfbue og 50.000 mennesker; et brændende, fugtigt helvede, klemt inde mellem den gule ørken, den blå himmel og Det indiske Ocean", skriver han under et besøg i 1960.

Det er 30 år før Black Hawk down, filmen der indædt spidder tragedien i Mogadishu om amerikansk idealisme, da den på Bill Clintons tid stadig eksisterede og var tænkt som en humanitær håndsrækning til et land, der var i nød. Men hvor det i stedet blev USA, der mavelandede og fik en bitter smag i munden af et Vietnam man havde bag sig og et Irak, der ventede forude.

Ingen i Israel har kunnet tage Herbert Pundik for givet, fra David Ben Gurion til Ariel Sharon. Pundik har udviklet sig fra at være frivillig soldat i Israels uafhængighedskrig i 1948 til han i dag fra sidelinjen kommenterer et Israel, som han forbeholder sig ret til at kritisere som det passer ham. Pundik kører ikke på frihjul.

\section{Det store historiske valg}

Efter hans søn Uris død under Oktoberkrigen sker der en langsom, men tydelig skærpelse af hans holdning til det Israel, der udvikler sig omkring ham. Hans kone, Sussi, og 
især hans datter har valgt fredsfløjen i det store indenrigspolitiske opgør. Det har Pundik det godt med. Han lader det ikke komme så tydeligt til udtryk, men netop i en antologi som denne kan man se, hvordan han er dybt involveret i det store historiske valg om, hvorvidt Israel skal fortsætte besættelsen af den palæstinensiske Vestbred og Gaza, eller gøre sig fri og redde egenarten i den jødiske stat, som han med egne hænder har hjulpet med at bringe til live i 1948 .

Der var engang en høg. Det var i de år, hvor Arbejderpartiet var ved magten, og Pundik skrev i partiorganet Davar. Da var alle i Israel høge. Israelerne erkendte først så småt, at de med 1967-erobringerne havde fået sig et stort Palæstinaproblem på halsen. Men alligevel levede Israel på Ben Gurions credo "Slå først hvis fjenden truer med et angreb". Det var det Menachem Begin bl.a. gjorde i 1981, da det israelske luftvåben med et lynangreb bombede og udslettede Iraks Osiris-reaktor.

Det er de samme overvejelser Israel i dag må gøre sig, hvis det bliver overbevist om, at Iran virkelig er på vej til at få atombomben. Israel kommer ikke til at leve under truslen om et iransk atombombeangreb. Ben Gurion-tænkningen gælder 100\%: Slå igen som svar på enhver fjendtlig situation. Før krigen på fjendens territorium!

Pundik lever med Israels pulsslag som var det hans eget, uanset hvor mange år han tilbragte i hjørne- værelset på Politiken. Der er to koncentriske cirkler der griber ind $\mathrm{i}$ hinanden og i Pundiks liv. Det ene er Israels Palæstinaproblem, som der skal findes en løsning på, før Israel drukner i sit selvskabte demografiske dilemma. Det andet er den mellemøstlige verden omkring Israel, de arabiske stater og Iran.

Enhver israeler elsker at optræde som ekspert på spørgsmålet om arabernes og iranernes hensigter. Men hos Pundik er det ikke lommeuld. Hans ajourførte analyser i Politikens ugentlige klummer er stadig noget af det skarpeste journalistik på Mellemøsten, der skrives herhjemme.

\section{Saddams raketter}

Det er ofte sagt, at Israel i modsætning til naboerne ikke kan tåle at tabe en krig. Derfor udløser angreb som 1967, 1973 og Saddam Husseins Scud-missiler i 1991 stort drama. Det er hudnær reportage, da Pundik beskriver den psykologiske virkning Saddams raketter har på ham. Luftalarm i Tel Aviv. Han og hans kone sidder på gulvet med børnebørnene i favnen, kikker betuttet på hinanden gennem gluggerne $\mathrm{i}$ gasmasker, håndklæder vædet $\mathrm{i}$ klorvand under dørene, en radiospeaker der forsøger at berolige befolkningen. 3000 lejligheder bliver ødelagt eller beskadiget af Saddams missiler. Pundik konstaterer tørt: "Fire måneder før vores 40-års bryllupsdag fortæller min kone mig, at gasmasken 


\section{LITTERATUR}

er blevet hendes bedste ven. 1-0 til

Saddam".

Da Pundik senere lander i Kastrup, siger tolderen: "Kan du huske hvad du sagde i tv? Du sagde, at der ikke ville blive krig i Golfen”.

Antologien viser, at Pundik ikke er bange for at medgive, at han ofte har taget fejl i sine forudsigelser. Ingen mellemøstlig kommentator får 100 pct ret. Heller ikke Vorherre.

Til gengæld er han - altså Pundik - helt klarøjet, forud for Irakkrigen, da han i oktober 2002 advarer om følgerne af en krig mod Saddam Hussein: "Irak vil efter Saddams fald stå $\mathrm{i}$ et dilemma mellem et nyt diktatur atter anført af en af vore banditter, eller opløsning som enhedsstat eller borgerkrig. Krigsherrerne, der i dag kontrollerer det såkaldt befriede Afghanistan, er for intet at regne med den situation, som kan opstå i post-Saddams Irak."

En af de ting, som alle har god grund til at beklage, er, at Oslo-processen ikke blev udmøntet i en endelig fredsaftale mellem Israel og PLO. Pundiks søn, Ron Pundak, var en af de centrale to skikkelser i Israel, der i dyb hemmelighed åbnede forhandlingerne i Norge med PLO. Så familien har i bogstavelig forstand oplevet de afgørende kapitler af Israels historie tæt inde på livet, og Herbert Pundik er eminent placeret som et vidne for sin tid i den del af verden.

Han skriver også medrivende, og ind i mellem faktisk morsomt, om
Afrika, Burma, Kina og meget mere. Men tilbage står Israel og dets naboer som den egentlige røde tråd, der løber gennem antologiens godt 300 sider. Det er jo i sagens natur ikke en gennemskrevet opsummering af forfatterens synspunkter. Det er derimod nedslag i de aktuelle begivenheder, mens de fandt sted. Det har for denne anmelder været det måske mest interessante ved denne bog. Den viser hvilke veje og vildveje, som vi alle på et tidspunkt så som sandhed. Man bliver klogere af Pundiks fejltagelser og især af hans eminente pletskud, hvor han bogstaveligt talt ser om hjørner og opdager de fejltagelser Mellemøstens politikere er på vej ind i.

Forfatteren og journalisten Morten Sabros har skrevet: "Dengang Gud skabte Pundik, havde han kedet sig i nogen tid. Nu vil jeg skabe noget virkelig morsomt, tænkte han, altså Gud. Så gik han ind i værkstedet, han blev derinde i syv lange og syv brede - men knap havde han sat det nye menneske fra sig, før det begyndte at pile rundt på bordet. Hvis ikke den mand bliver cirkusartist, tænkte Gud. Så vil han blive en af de helt store journalister. Jeg tror, jeg vil kalde ham Pundik, det er et godt navn til sådan én".

Jens Nauntofte er udenrigspolitisk kommentator og forfatter. Han har beskeftiget sig med Israel og Mellemøsten, siden han boede der forste gang i 1961-62. 